DOI: https://doi.org/10.34069/AI/2021.43.07.7

How to Cite:

Bashkir, O., Kniaz, H., Panchenko, V., Bakhmat, L., \& Sobchenko, T. (2021). Conditions for forming future language teachers' lexical competence in pandemic times. Amazonia Investiga, 10(43), 72-82. https://doi.org/10.34069/AI/2021.43.07.7

\title{
Conditions for forming future language teachers' lexical competence in pandemic times
}

\section{Умови формування лексичної компетентності майбутніх учителів-філологів у період пандемії}

\author{
Written by: \\ Olha Bashkir ${ }^{22}$ \\ https://orcid.org/0000-0001-5237-9778 \\ Hanna Kniaz ${ }^{23}$ \\ https://orcid.org/0000-0002-2485-5367 \\ Violetta Panchenko ${ }^{24}$ \\ https://orcid.org/0000-0002-2958-5802 \\ Liudmyla Bakhmat ${ }^{25}$ \\ https://orcid.org/0000-0002-4990-0443 \\ Tetiana Sobchenko ${ }^{26}$ \\ https://orcid.org/0000-0002-9213-5556
}

\begin{abstract}
Successful communication in English as a foreign language depends primarily on the amount of vocabulary learned, which ensures speech appropriateness in a particular communicative situation and adequate perception of information. The article reveals the conditions for forming future language teachers' lexical competence in Ukrainian higher pedagogical education institutions on the example of vocabulary denoting coronalogisms. The summative stage revealed students' positive motivation for learning new vocabulary, while the formative one was aimed at expanding students' range of vocabulary on a particular topic. The work was carried out in three stages: introducing new vocabulary; practicing and consolidating new material; using the target vocabulary in written and oral speech. Determining the range of students' vocabulary, their word knowledge quality and ability to use target vocabulary at the control stage gives grounds to state the effectiveness of conditions
\end{abstract}

\begin{abstract}
Анотація
Успішність практичного використання англійської мови як іноземної залежить насамперед від обсягу засвоєної лексики, оскільки саме вона забезпечує коректність сформульованих висловлювань у конкретній ситуації спілкування і правильність сприйняття інформації ззовні. У статті розкрито умови формування лексичної компетентності майбутніх учителів-філологів закладів педагогічної освіти України на прикладі лексики на позначення короналогізмів. На констатувальному етапі виявлено позитивну мотивацію здобувачів освіти до оволодіння новою лексикою. Робота на формувальному етапі була спрямована на формування в студентів належного об'єму словникового запасу 3 конкретної теми та здійснювалася на трьох етапах: ознайомлення та семантизації нової лексики; відпрацювання та закріплення нового матеріалу; використання засвоєних лексичних одиниць у писемному та усному мовленні. Визначені об’єм словникового
\end{abstract}

\footnotetext{
${ }^{22}$ Doctor of Pedagogical Sciences, Associate Professor, Professor of the Department of Educology and Innovative Pedagogy, H. S. Skovoroda Kharkiv National Pedagogical University, Ukraine.

${ }^{23}$ Candidate of Philological Sciences, acting Dean of Foreign Philology Faculty, H. S. Skovoroda Kharkiv National Pedagogical University, Ukraine.

${ }^{24}$ Candidate of Pedagogical Sciences, Senior Lecturer of the Foreign Philology Department, Municipal Establishment "Kharkiv Humanitarian Pedagogical Academy" of Kharkiv Regional Council, Ukraine.

${ }^{25}$ Candidate of Pedagogical Sciences, Associate Professor of the Foreign Philology Department, Municipal Establishment "Kharkiv Humanitarian Pedagogical Academy" of Kharkiv Regional Council, Ukraine.

${ }^{26}$ Candidate of Pedagogical Sciences, Associate Professor, Associate Professor of the Department of Educology and Innovative Pedagogy, H. S. Skovoroda Kharkiv National Pedagogical University, Ukraine.
} 


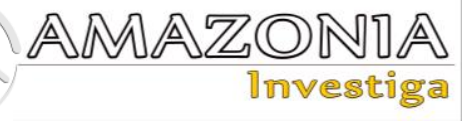

for forming future language teachers' lexical competence during the pandemic: using ICT and time-conditioned blended learning as a combination of traditional and distance learning.

Keywords: lexical competence, coronalogisms, foreign language, information and communication technologies, blended learning.

\section{Introduction}

Competence-based approach and creating conditions for the formation of students' appropriate competencies occupy the leading position in the restructuring of the education system. New standards of the competence education paradigm call for introducing innovative approaches and technologies in the training of future language teachers. The Law of Ukraine "On Higher Education" (Law No 1556VII, 2021) states that competencies are dynamic combinations of knowledge, skills and abilities, practical know-how; ways of thinking; professional, ideological and civic qualities; moral and ethical values that determine a person's ability to successfully carry out professional and further educational activities, obtained at a certain level of higher education.

The subject of pedagogical theory and practice is the problem of introducing a new modern competence approach in higher education institutions (HEI) and, accordingly, the formation of future language teachers' competencies. The current professional standard and the order of the Ministry of Economic Development, Trade and Agriculture №2736 of 23.12.2020 define personal characteristics of the teacher (emotional and ethical competency) and professional competencies (Ministry for Development of Economy, Trade and Agriculture of Ukraine, 2020).

\section{LiteratureReview}

It is worth mentioning that linguistic communicative competency is the key one in the structure of professional competencies of future language teachers. Drozd (2017) believes that speaking about foreign language teachers' linguistic communicative competency we indicate two main groups of skills: proper communicative (establish contact with interlocutors, maintain conversation, produce запасу, якість знань слів і здатність послуговуватися новою лексикою на контрольному етапі дають підстави стверджувати ефективність умов формування лексичної компетентності майбутніх учителівфілологів у період пандемії: використання інформаційно-комунікативних технологій та зумовлене часом змішане навчання як поєднання традиційного та дистанційного.

Ключові слова: лексична компетентність, короналогізми, іноземна мова, інформаційнокомунікативні технології, змішане навчання.

utterances of different styles and genres, ability to engage students in learning the subject). and professional-communicative (good command of vocabulary, didactic and linguistic terminology; implementation of educational communication through language means realizing the aesthetic function of language, represent the beauty and richness of language; the ability to produce educational discourse, paraphrase, identify and correct mistakes in their own and their students' speech, etc.)

Despite the perfection of the system, language has the potential to adapt to the needs of society, the language community. Academician Rusanivsky (1988) was convinced that the main function of language is to reflect the progress of society, because it is designed to consolidate and accumulate human experience and promote its exchange in the process of creating material and spiritual culture. In general, language dynamics is characterized by three processes: evolution, development and improvement.

The vocabulary of the English language is constantly changing and replenished with new lexical units. The most common areas of neologisms are those that are characterized by change and innovation, i.e. modern technology, scientific progress. However, in 2020, the field of medicine gained unprecedented popularity. The interest of the world community was caused by the emergence of a new type of coronavirus, which led to a global pandemic (Burgos, 2020; Moran \& Raycraft, 2020).

On July 3, 2020, Global Language Monitor (GLM) announced that the most popular word of 2020 was Covid (Payack, 2020). According to GLM, 24 of the 50 highest-rated words are related to the pandemic, with 17 of them in the top 30 . 
The editor-in-chief of the Oxford Dictionary of English (Paton, 2020) claims that lexicographers, trying to update the vocabulary in time, take into account the extraordinary events of 2020 and make changes to the usual quarterly cycle of publications. But in these extraordinary times, when lexicographers of the Oxford English Dictionary work from home, like many others in the world, they constantly monitor the development of the pandemic language and offer the linguistic and historical context of their use. According to the calculations of Tony Thorne, Language Consultant at King's College London more than 1000 changes have been made so far (Moran \& Raycraft, 2020).

The emergence of coronalogisms and the relevance of their introduction in medicine and in everyday speech has led to the inclusion of such vocabulary in English language curriculum at the faculties of foreign languages in Ukrainian higher pedagogical education institutions.

Dynamism, transformations in knowledge, technologies, living conditions led to the introduction of blended learning, which includes a combination of traditional (offline) learning and distance (online) learning. Thus, HEI instructors faced the challenge to choose effective tools and services of information and communication technologies to ensure the organization of high-quality educational process and achieving expected learning outcomes.

The importance of the development of personal lexical competence was emphasized by Velasco (2007), Yuksel (2011), Rasuoli \& Jafari (2016), Galetskyi (2020), Bashkir \& Ilchenko (2020). The issues of introducing coronalogisms into the language are covered in the works by Burgos (2020), Lawson (2020), Mahdawi (2020) and others. Meara (1996), Chan et. al. (2011) devoted their researches to the peculiarities of using ICT in the process of vocabulary acquisition.

\section{Methodology}

The purpose of the article is to determine the conditions for the formation of future language teachers' lexical competence by means of information and communication technologies in the system of blended learning in a higher pedagogical education institution.

The study has been conducted in H. S. Skovoroda Kharkiv National Pedagogical University and Municipal Establishment "Kharkiv Humanitarian Pedagogical Academy" of Kharkiv Regional Council since 2020 and is being carried on currently. 117 students participated in the study, among them 36 students of Ukrainian Language and Literature Faculty named after G. F. Kvitka-Osnovyanenko, 44 students of the Faculty of Foreign Philology of H. S. Skovoroda Kharkiv National Pedagogical University and 37 students of the Faculty of Social Sciences and Foreign Philology of Municipal Establishment "Kharkiv Humanitarian Pedagogical Academy" of Kharkiv Regional Council. All participants gave their written consent to take part in the pedagogical experiment.

The effectiveness of the formation of future language teachers' lexical competence in HEI was determined on the grounds of the chosen set of coronalogisms as well as taking into account developed components and criteria for this competence acquisition. The above mentioned factors provided the possibility of purposeful pedagogical influences in the system of blended learning:

1. The motivational component was evaluated according to the motivational-target criterion, which is characterized by the following indicators: awareness of the role of lexical competence in future professional activities; positive attitude to acquiring lexical competence; prevalence of positive cognitive motives, aspiration for achieving professional excellence.

2. The content component was evaluated by a cognitive criterion, which is characterized by the following indicators: vocabulary range; the quality of active and passive vocabulary.

3. The activity component was evaluated by a procedural-behavioural criterion, which is characterized by the ability to use new vocabulary in new learning or everyday environment.

4. The reflective component was evaluated according to the reflective-result criterion, which is characterized by the following indicators: constant adjustment of speech, reflection on the results and planning further communication.

The following methods were used in the study: analysis, observation, interviews, mathematical calculations. The study was carried out in three stages: summative, formative and control.

The summative stage involved analysing the content of the curricula, which revealed the need to introduce vocabulary denoting coronalogisms in order to purposefully organize its study by 


\section{AMAZONDA \\ Tovestiga}

second-year students - future language teachers. Observations and interviews revealed a low level of students' vocabulary range; the quality of active and passive vocabulary needed clarification and explanation, students lacked the ability to use new vocabulary in new learning and everyday environments.

Awareness of their own motives for acquiring lexical competence by future language teachers was determined using the methodology

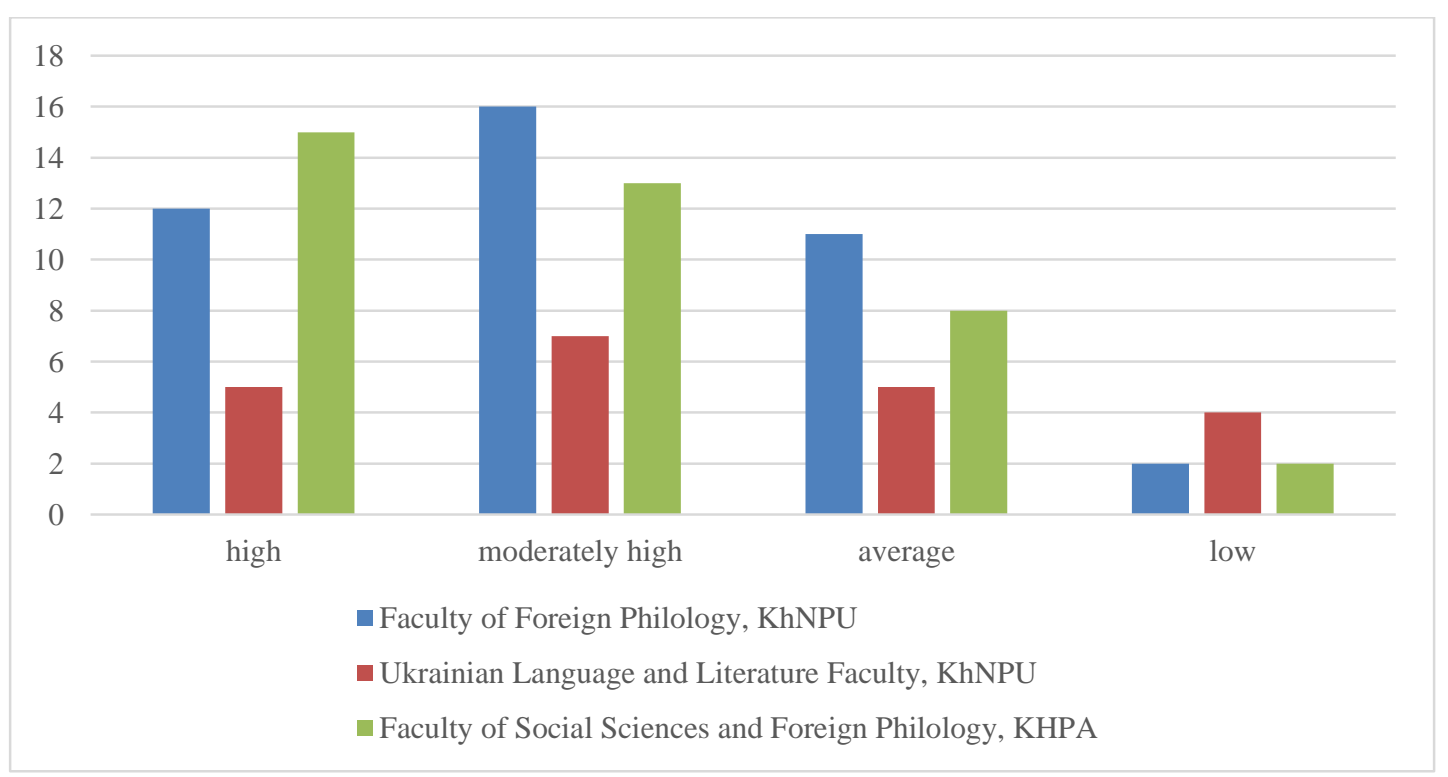

Fig. 1. The results of the motivation evaluation.

The formative stage of the study showed that $68 \%$ of students had a high and moderately high level of motivation (over 200-151 points). Moreover, students of the faculties of foreign philology of both education institutions had a more pronounced active position. $24 \%$ of students scored 150-111 points and had an average level of motivation. Only $8 \%$ were indifferent to the study of vocabulary denoting coronalogisms, which indicated a low level of motivation.

Thus, the methodology used to identify future language teachers' motivation to acquire lexical competence showed their awareness of the role of lexical competence in their future professional activities; positive attitude to acquiring lexical competence; prevalence of positive cognitive motives, aspiration for achieving professional excellence.

\section{Results and Discussion}

The formative stage was conducted in the conditions of blended learning and aimed at
"Determination of learning motivation" (V. Katashev) and the methodology "Motivation to study in a higher education institution" (T. Ilina), which were modified by the authors. The methodology contained two groups of questions on the volitional and emotional spheres. The results were directly related, i.e. the higher the score, the higher the level of motivation. The maximum number of points was 220. Figure 1 presents the results of the questionnaire. 
led-to-an-explosion-of-new-words-and-phrasesand-that-helps-us-cope-136909,

https://www.abc.net.au/news/2020-06-14/mileycyrus-coronavirus-covid19-cockney-rhymingslang/12324930,

https://www.cbc.ca/radio/thecurrent/the-currentfor-april-22-2020-1.5540906/covidiots-

quarantinis-linguist-explains-how-covid-19-hasinfected-our-language-1.554091, etc.). The use of authentic materials allowed us to present the language in a living context, to arrange real-life communicative situations in class and to demonstrate the language in action.

The services Quizlet and Kahoot! were used at the stage of practicing and consolidating new material. A vocabulary set consisting of words, phrases and set expressions on the topic "Coronalogisms" was created on Quizlet. Students had the opportunity to practice lexical units in several modes: 1) Flashcards memorising new words with the help of cards, on one side of which the term is written, and on the back there is the definition; 2) Learn - guessing words or expressions by writing them in a special line; 3 ) Spell - typing words pronounced by the native speaker; 4) Match - correlation of the lexical unit with the picture / synonym; 5) Gravity - gamified vocabulary practice when students have to type target words as quickly as possible to stop asteroids from hitting the planet.

These types of activities trigger all channels of information perception, which contributes to better vocabulary acquisition. In addition, students not only memorize the meaning of lexical items, but also train their correct pronunciation, spelling, learn to paraphrase, find synonyms/antonyms.

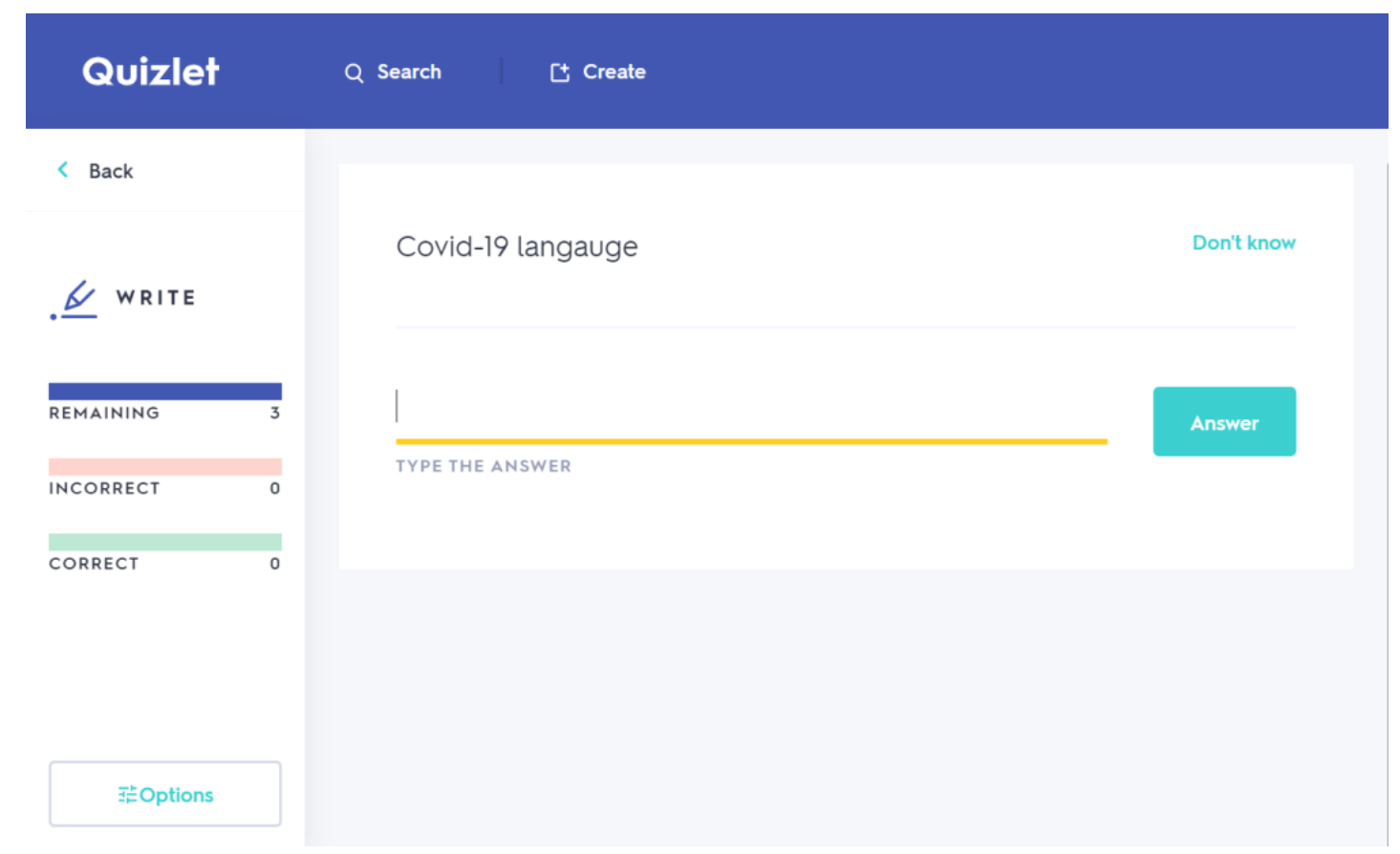

Fig. 2. Quizlet Set of Coronalogisms.

Similar tasks can also be created on the Kahoot! platform. We developed a quiz to practice the meanings of neologisms with the root 'corona'.
Students had to choose one of the four suggested meanings of the lexical unit. 


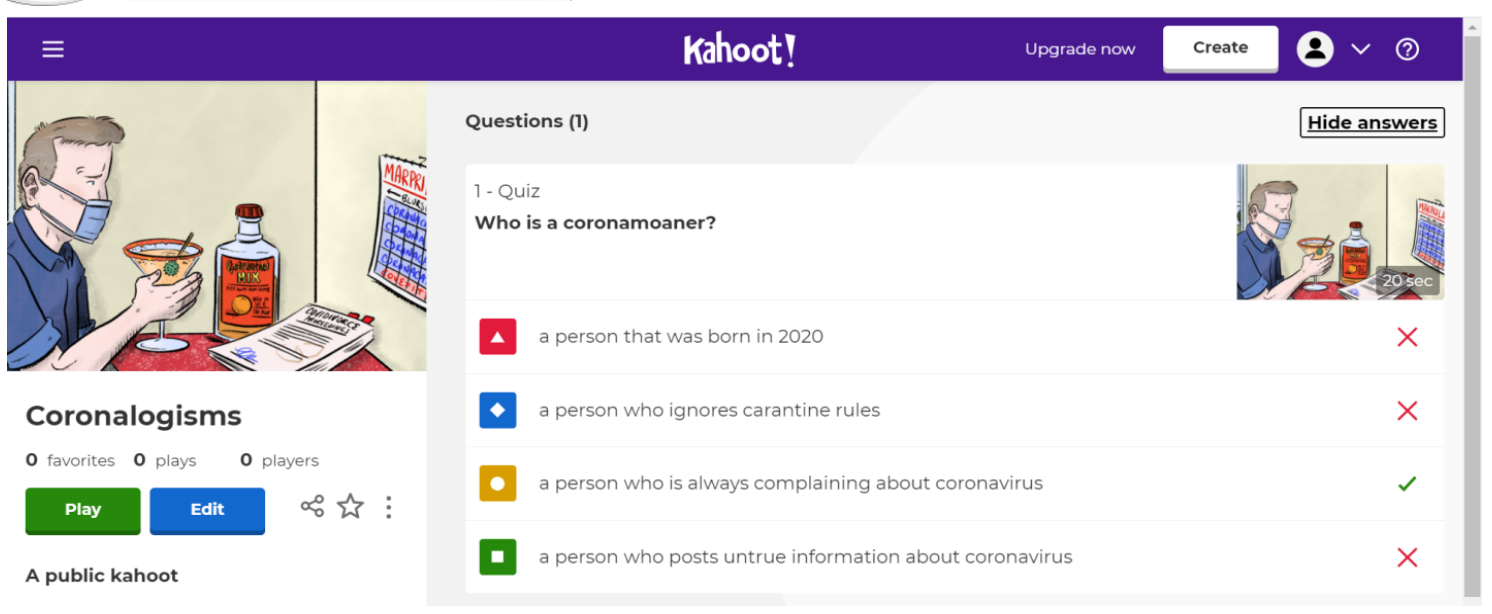

Fig. 3. Kahoot Quiz Coronalogisms.

The tasks developed on the Online Test Pad platform also contributed to the consolidation of the new vocabulary. We offered students exercises on developing word-formation skills, where it was necessary to combine the most commonly used roots of neologisms caused by the COVID-19 pandemic to obtain new words.

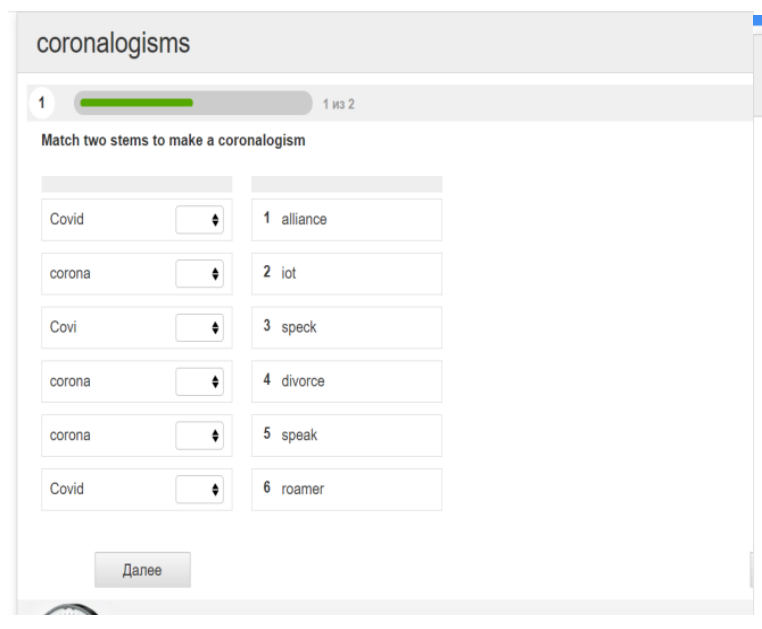

Fig. 4. Online Test Pad Tasks on Coronalogisms.

After mastering the basic vocabulary, students were asked to create interactive images on the ThingLink platform. The content of the interactive tags contained general information about the coronavirus, links to the websites with databases of scientific articles in the medical and
Another effective way to consolidate lexical material is to fill in the gaps in the text. In this case, students were offered a list of sentences that they had to complete by choosing one of the options from the drop-down list, which contained active vocabulary units.

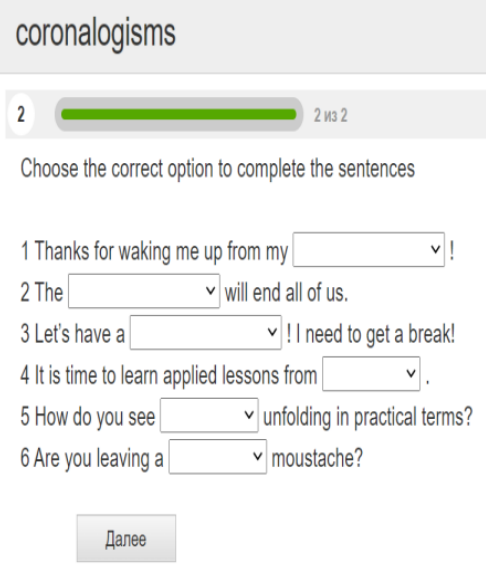

philological fields related to COVID-19, interactive maps of the coronavirus distribution worldwide, etc. Students exchanged interactive images and provided feedback through a questionnaire offered by the teacher via Telegram Messenger. 


\section{CORONAVIRUSS Symptoms I Transmission I Prevention I Treatment}
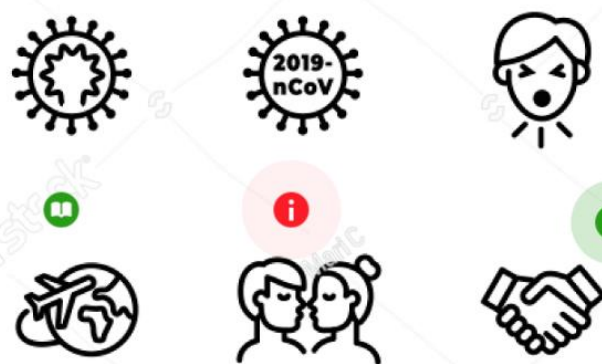

(i)
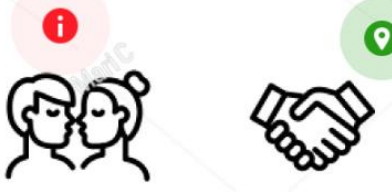

$\circ$

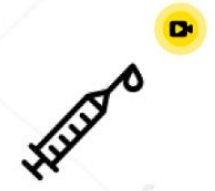

Fig. 5. ThingLink Interactive Image.

The next stage in the formation of lexical competence involved using the target vocabulary in written and oral speech. Thus, students had to create their own fairy tale or story, using as many lexical units from the active vocabulary on the
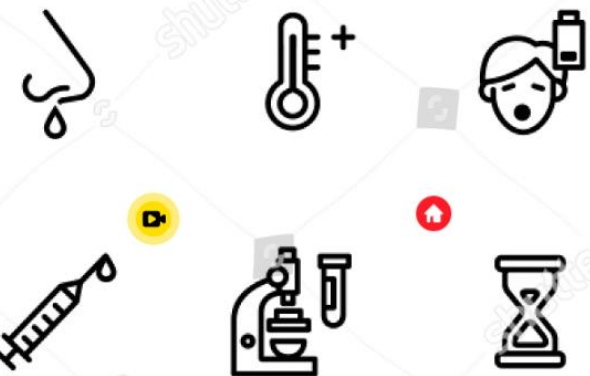

(4)

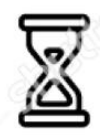

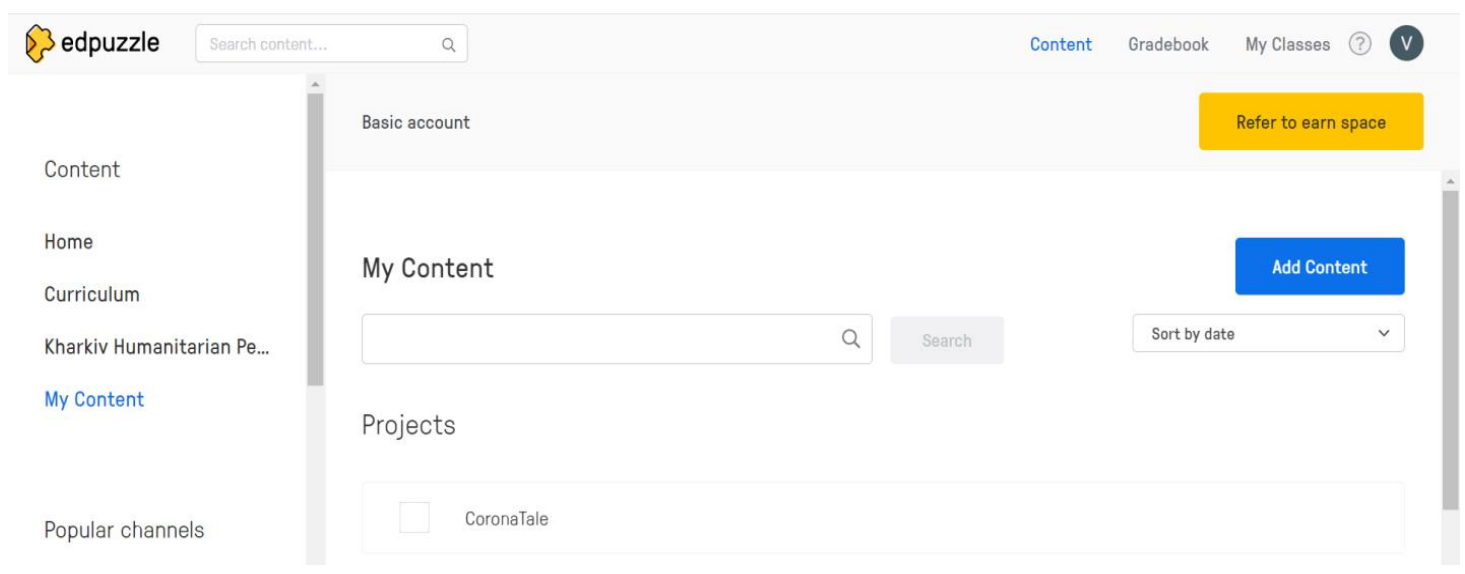

Fig. 6. Edpuzzle Project CoronaTale.

The Flipgrid platform was offered as an alternative application at the final stage of lexical competence formation. It provided an opportunity to share video recording lasting up to 90 seconds. Students were asked to record a video message on the topic "How to tackle topic "Coronalogisms" as they could. Videos were created independently or selected from the ready-made content, but were voiced by students in accordance with the plot they came up with.
COVID-19" and demonstrate knowledge of lexical units on the subject. In addition to oral speech practice, the platform provides for the exchange of written messages, comments after watching video messages, which contributed to honing skills of written speech. 


(4) Flipgrid Discussion Discovery
Discussion > Test group (KhNPU) > How to tackle COVID-19
Jan 30, 2021
How to tackle COVID-19
0 responses - 0 views · o comments • o hours of engagement
Prepare a small talk about what you should know about COVID-19 to
protect yourself and others
Join Code: a244d1e9

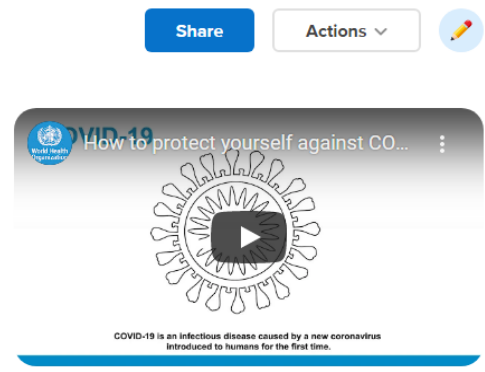

Fig. 7. Flipgrid Video Discussion (How to tackle COVID-19).

The main tasks of the control stage of the research were to study and explain qualitative and quantitative changes in the formation of students' lexical competence, which were obtained in the course of the work; to analyse the results of the formative stage (verification of the effectiveness of ICTs used); drawing general conclusions.

The same methods (observation, interviewing) were used to measure the level of students' lexical competence, which were used at the summative stage.

The results of diagnosing the level of knowledge of new vocabulary and students' motivation to acquiring lexical competence at the summative stage of the study show that the high level (11\% of students) is characterized by the awareness of the role of lexical competence in future professional activities; positive attitude to learning target vocabulary; a wide range of active and passive vocabulary; ability to use new vocabulary in learning and everyday environments, continuous reflection on the results and planning further communication.

The average level $(25 \%)$ is characterized by the fact that students do not always aspire for learning neologisms, preferring traditional vocabulary, which is included in the curricular of higher education institutions. However, they have a positive attitude to acquiring lexical competence in particular and professional skills in general; know a sufficient amount of vocabulary; are able to modify their speech depending on the situation and instructions of the teacher, partially rethink and predict the results of further communication.

Students who are at the low level (64\%) have a rather limited vocabulary; low quality of word knowledge, are not able to use target vocabulary in new learning and everyday environments, do not modify their speech, but demonstrate a positive attitude to acquiring lexical items that denote coronologisms.

Thus, the results of the summative stage of the study revealed a rather low level of students' lexical competence and the need for special and purposeful work on the use of ICT in blended learning mode.

The results of implementing ICT into the training of future language teachers are illustrated by Table 1. 
Table 1

The levels of the lexical competence formation (\%)

\begin{tabular}{|c|c|c|c|c|c|}
\hline 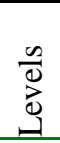 & 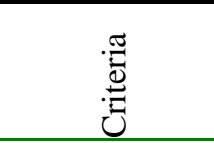 & Indicators & 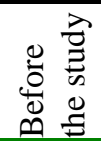 & 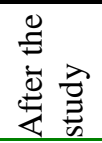 & 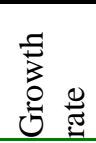 \\
\hline \multirow{6}{*}{ 불 } & $\begin{array}{l}\text { Motivational- } \\
\text { target }\end{array}$ & $\begin{array}{l}\text { Awareness of the role of lexical competence in future } \\
\text { professional activities; positive attitude to acquiring } \\
\text { lexical competence; prevalence of positive cognitive } \\
\text { motives, aspiration for achieving professional expertise }\end{array}$ & 88 & 100 & 12 \\
\hline & Cognitive & $\begin{array}{l}\text { A wide range of active and passive vocabulary; high } \\
\text { quality word knowledge. }\end{array}$ & 12 & 51 & 39 \\
\hline & $\begin{array}{l}\text { Procedural- } \\
\text { behavioural }\end{array}$ & $\begin{array}{l}\text { Ability to easily use target vocabulary in new learning } \\
\text { and everyday environments }\end{array}$ & 6 & 35 & 29 \\
\hline & Reflective & $\begin{array}{l}\text { Constant adjustment of speech, reflection on the results } \\
\text { and planning further communication }\end{array}$ & 22 & 39 & 17 \\
\hline & $\begin{array}{l}\text { Motivational- } \\
\text { target }\end{array}$ & $\begin{array}{l}\text { Superficial awareness of the role of lexical competence } \\
\text { in future professional activity; neutral attitude to } \\
\text { acquiring lexical competence; episodic manifestation of } \\
\text { the desire to achieve professional expertise }\end{array}$ & 12 & - & - \\
\hline & Cognitive & $\begin{array}{l}\text { Sufficient range of active and passive vocabulary; } \\
\text { sufficient quality of word knowledge }\end{array}$ & 17 & 49 & 32 \\
\hline \multirow{3}{*}{ 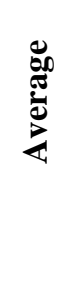 } & $\begin{array}{l}\text { Procedural- } \\
\text { behavioural }\end{array}$ & $\begin{array}{l}\text { Episodic use of target vocabulary in new learning and } \\
\text { everyday environments }\end{array}$ & 19 & 65 & 46 \\
\hline & Reflective & $\begin{array}{l}\text { Situational adjustment of speech, partial rethinking and } \\
\text { planning of further communication }\end{array}$ & 49 & 61 & 12 \\
\hline & $\stackrel{3}{\stackrel{3}{3}}$ & $\begin{array}{l}\text { Indicators are not fully manifested. In particular, there } \\
\text { is indifference to the mastery of lexical competence, } \\
\text { lack of desire for self-improvement. }\end{array}$ & - & - & -33 \\
\hline
\end{tabular}

Source: compiled by the authors.

The analysis of Table 1 proves the effectiveness of implementing ICT in the conditions of blended learning during the formative stage of the research. According to the motivational-target criterion, the growth rate is $+12 \%$ at the high level, at the average level the growth rate is observed in students' transition to a higher level of motivation, which indicates raising students' awareness of the role of lexical competence in their future professional activity, prevailing of positive cognitive motives, aspiration for professional expertise. The growth rate according to the cognitive criterion is $+39 \%$ at the high level, and $+32 \%$ at the average level, which indicates that future language teachers have a wide range of active and passive vocabulary; high quality word knowledge. According to the indicators of procedural and behavioural criteria, the growth rate is $+29 \%$ at the high level, $+46 \%$ at the average level, which manifests students' ability to easily use target vocabulary in new learning and everyday conditions. The growth rate according to the reflective criterion is $+17 \%$ at the high level, and $+12 \%$ at the average level respectively, which demonstrates the proper formation of students' abilities to constantly adjust their speech, reflect on the results and plan further communication.

\section{Conclusions}

The formation of future language teachers' lexical competence is manifested in their range of active and passive vocabulary on a particular topic, while the quality of word knowledge ensures their ability to use target vocabulary in new learning and everyday conditions.

The research was aimed at the formation of future language teachers' lexical competence on coronalogisms in the conditions of blended learning in higher pedagogical education institutions.

The study was conducted among second-year students of philological faculties of pedagogical universities of Ukraine in three stages: summative, formative and control. The summative stage revealed students' positive motivation for learning new vocabulary, which testifies to its relevance, but the level of students' vocabulary was quite low. The formative stage was aimed at expanding students' range of 


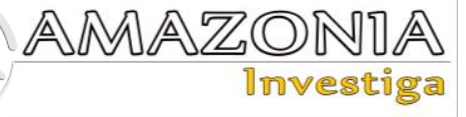

vocabulary on a particular topic, improving the quality of word knowledge, their ability to use new vocabulary in new learning and everyday conditions. The work was carried out in three stages: introduction of new vocabulary; practicing and consolidating new material; using the target vocabulary in written and oral speech.

Determining the range of students' vocabulary, their word knowledge quality and ability to use target vocabulary at the control stage gives grounds to state the effectiveness of conditions for the formation of future language teachers' lexical competence during the pandemic: the use of information and communication technologies (YouTube, Quizlet, Kahoot, OnlineTestPad, Edpuzzle, Thinglink, Flipgrid) and timeconditioned blended learning as a combination of traditional and distance learning.

\section{References}

Bashkir, O., \& Ilchenko, A. (2020). Building lexical competence of learners on English lessons. Topical Issues in the Humanities: Intercollegiate Collection of Scientific Papers of Young Scientists of Ivan Franko Drohobych State Pedagogical University, 33(1), 262-267. https://doi.org/10.24919/2308-

4863.1/33.215740

Bodle, A. (2016, February 4). How new words are born. The Guardian. Retrieved from https://www.theguardian.com/media/mind-yourlanguage/2016/feb/04/english-neologisms-newwords

Burgos, R. (2020). How the COVID-19 pandemic changed language. Languagewire. Retrieved from https://www.languagewire.com/en/blog/howthe-covid-19-pandemic-changed-language Caro, K., \& Rosado, N. (2017). Lexis, Lexical Competence and Lexical Knowledge: A Review. Journal of Language Teaching and Research, $8(2)$, 205-213. https://doi.org/10.17507/jltr.0802.01

Chan, W. M., Chin, K. N., Nagami, M., \& Suthiwan T. (2011). Media in foreign language teaching and learning. Studies in second and foreign language education. Boston. Walter de Gruyter.

Drozd, T. (2017). Development of communicative competence of teachers of philological specialities in the system of postgraduate education. (Candidate of Pedagogical Sciences dissertation), Vinnytsia Academy of Continuing Education, Ukraine. Retrieved from https://www.vspu.edu.ua/content/specialized_ac ademic_council/doc/2017/Drozd_T/dis.pdf
Galetskyi, S. (2020). The formation of communicative competence of future foreign language teachers by the means of information and communication technologies. (Candidate of Pedagogical Sciences dissertation). Zhytomyr Ivan Franko State University, Ukraine. Retrieved from

http://eprints.zu.edu.ua/31122/1/dys_Galetskyi. pdf

Ilyashenko, L., Gladkova, M., Kutepov, M., Vaganova, O., \& Smirnova, Z. (2019). Development of communicative competencies of students in the context of blended learning. Amazonia Investiga, 8(18), 313-322. Retrieved from

https://amazoniainvestiga.info/index.php/amazo nia/article/view/313

Law No 1556-VII, 'On Higher Education', Parliament of Ukraine of 23.04.2021. Retrieved from https://zakon.rada.gov.ua/laws/show/155618\#Text

Lawson, R. (2020, April 28). Coronavirus has led to an explosion of new words and phrases - and that helps us cope. The Conversation. Retrieved from https://theconversation.com/coronavirushas-led-to-an-explosion-of-new-words-andphrases-and-that-helps-us-cope-136909

Mahdawi, A. (2020, April 15). From Covidiot to doomscrolling: How coronavirus is changing our language. The Guardian. Retrieved from https://www.theguardian.com/commentisfree/20 20/apr/15/from-covidiot-to-doomscrolling-howcoronavirus-is-changing-our-language

Meara, P. (1996). The Dimensions of Lexical Competence. In G. Brown, K. Malmkjaer and J. Williams (Eds.), Performance and competence in second language acquisition (pp. 35-53). Cambridge: Cambridge University Press.

Ministry for Development of Economy, Trade and Agriculture of Ukraine (2020). Professional standard of a primary school teacher, secondary education institution teacher. Retrieved from https://zakon.rada.gov.ua/rada/show/v273691520\#Text

Moran, P. \& Raycraft, R. (2020, April 22). Covidiots? Quarantinis? Linguist explains how COVID-19 has infected our language. Message posted

to https://www.cbc.ca/radio/thecurrent/the-currentfor-april-22-2020-1.5540906/covidiotsquarantinis-linguist-explains-how-covid-19-hasinfected-our-language-1.5540914

Oxford English Dictionary. Retrieved from https://www.oed.com

Paton, B. (2020 April 9) Social change and linguistic change: the language of Covid-19. Oxford English Dictionary. Retrieved from https://public.oed.com/blog/the-language-ofcovid-19/ 
Payack, P. (2020, July 3). Global Language Monitor Announces That 'Covid' is the Top Word of 2020. Global Language Monitor. Retrieved from https://languagemonitor.com/pandemic/globallanguage-monitor-announces-that-covid-is-thetop-word-of-2020/

Rasuoli, F, \& Jafari, K. (2016). A Deeper Understanding of L2 Vocabulary Learning and Teaching. A Review Study. International Journal of Language and Linguistics, 4(1), 40-46. Retrieved from http://article.sciencepublishinggroup.com/html/ 10.11648.j.ijll.20160401.16.html

Rusanivskyi, V. (1988). The structure of lexical and grammatical semantics. Kyiv: Naukova dumka.

Vaganova, O., Livshits, Y., Aleshugina, E., Smirnova, Z., \& Kutepova, L. (2019). Experience in developing electronic glossary in a higher education institution. Amazonia
Investiga, 8(22), 247-253. Retrieved from https://amazoniainvestiga.info/index.php/amazo nia/article/view/421

Velasco, D. (2007). Lexical competence and Functional Discourse Grammar. Alfa: Revista de Lingüística, 51(2). Retrieved from https://www.researchgate.net/publication/26623 402_Lexical_competence_and_Functional_Disc ourse_Grammar

Yuksel, I. (2011). Evaluation of Foreign Language Learners' Lexical Competence. Problems of Education in the 21st century, 36, 10-16. Retrieved from http://www.scientiasocialis.lt/pec/files/pdf/vol3 6/10-16.Yuksel_Vol.36.pdf

Zareva, A., Schwanenflugel, P., \& Nikolova, Y. (2005). Relationship between lexical competence and language proficiency: variable sensitivity. Studies in Second Language Acquisition, 27(4), 567-595. https://doi.org/10.1017/S0272263105050254 